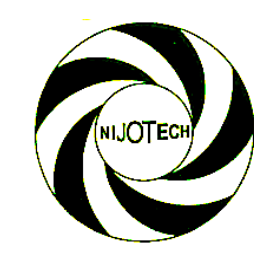

Nigerian Journal of Technology (NIJOTECH)

Vol. 39, No. 3, July 2020, pp. 839 - $\mathbf{8 4 3}$

Copyright@ Faculty of Engineering, University of Nigeria, Nsukka,

Print ISSN: 0331-8443, Electronic ISSN: 2467-8821

www.nijotech.com

http://dx.doi.org/10.4314/nit.v39i3.25

\title{
DESIGN OF 0.67HP GASOLINE GENERATOR PISTONS
}

\author{
B. N. G. Aliemeke ${ }^{1, *}$ and M. H. Oladeinde ${ }^{2}$ \\ 1, Department of Mechanical Engineering, Auchi Polytechnic, Auchi, Edo State, Nigeria \\ 2, Department of Production Engineering, University of Benin, Benin City, Edo State, NiGeRIA
}

Email addresses: ${ }^{1}$ aliemeka@yahoo.com, ${ }^{2}$ moladeinde@uniben.edu

\begin{abstract}
Piston is an important internal combustion engine component that works with other engine components to withstand severe stresses and high temperature that are generated in the combustion chambers. Pistons are subjected to a very high mechanical and thermal load which results from extreme pressure cycles and huge forces of inertia caused by extremely high acceleration during the reciprocating motion. The $0.67 \mathrm{hp}$ generator piston designed had the values of parameters to be: $51.00 \mathrm{~mm}$ Piston stroke; $48.85 \mathrm{~mm}$ piston bore diameter; $3.66 \mathrm{kw}$ brake power; $4.87 \mathrm{kw}$ indicated power; $11.63 \mathrm{Nm}$ engine torque; $3.22 \mathrm{~mm}$ piston thickness and $9.44 \mathrm{~cm}^{3}$ clearance volume. The piston parameter values calculated were found to be in accordance with the recommended range of values in the design and operating data for internal combustion engines.
\end{abstract}

Keywords: Piston design, machine parameters and internal combustion engines.

\section{INTRODUCTION}

Piston is one of the most complex components of an internal combustion engine which converts heat energy into mechanical energy [1]. Pistons are subjected to a very high mechanical and thermal load which result in huge forces of inertia caused by extremely high acceleration during the reciprocating motion in the engine cylinder [2]. It is apparent from the automobile combustion of the fluids that the piston component in the internal combustion engine encounters combustion products such as carbon monoxide ( $\mathrm{CO}$ ) and carbon which are frequently deposited on the piston crown [3].

A good piston material is expected to possess a plethora of mechanical properties. According to [4] refined structure, minimum porosity, hardness, high tensile strength, high fatigue strength, high strengthto-weight ratio, good wear resistance, weldability, heat-treatability, near-net shape manufacture, good surface quality and better dimensional accuracy are major advantages of metal casting.

Nnewi, the second largest city in Anambra State is known to be "Japan of Africa". It is a home to many indigenous manufacturing companies like Ibeto Group, Chicason Group and Innoson Group which are known specialists for the manufacture of auto spare parts of motorcycles, generators and vehicles [5].

In the recent times there has been huge challenges facing the production of automotive spare parts for the Automotive industry in Nigeria [6]. The Federal Government of Nigeria had entered into agreement of production with Automotive industry investors like Anambra Motor Manufacturing Company (ANAMCO), Peugeot Automobile of Nigeria (PAN), Volkswagen Nigeria Limited (VNL), Leylands Nigeria Limited (LNL) and National Truck Nigeria Limited (NTNL) by implementing automotive policy that will ensure that various auto spare parts are manufactured in Nigeria. This was done in a bid to bring about technological advancement for the country [7]. This arrangement did not last for long because of the various problems beleaguering the sector.

Nigerian researchers have embarked on study of pistons manufacture. A Yamaha piston of aluminium alloy material was made on the basis of functional requirement like low thermal expansion, low specific gravity, wear resistance, tensile strength and high thermal conductivity [8]. A single-cylinder diesel engine pistons using Reverse engineering technique was developed by [9] in University of Benin, Nigeria. The study showed that the utilized cast iron

\footnotetext{
* Corresponding author, tel: +234-803-064-8051
} 
composite used as raw material produced 788rpm engine speed during testing. Similarly, [10] used reversed engineering approach to produce $3 \mathrm{hp}$ petrol generator engine pistons.

This present study is geared towards designing $0.67 \mathrm{Hp}$ gasoline generator pistons which will be used to manufacture pistons from recycled scrap aluminium alloy. It will uniquely serve as a template on which other kinds of gasoline and diesel pistons can be produced. In addition it will engender the development of local content in piston design and elimination of dependence on Reverse engineering in production of engine component like piston.

Engine piston comprises of a cylindrical crown which tapers to a thinner section and a cylindrical skirt situated below the pressure rings, keeping the piston in alignment with the engine cylinder [11]. The important features of the piston are shown in Figure 1. This study is aimed at designing $0.67 \mathrm{Hp}$ gasoline generator piston.

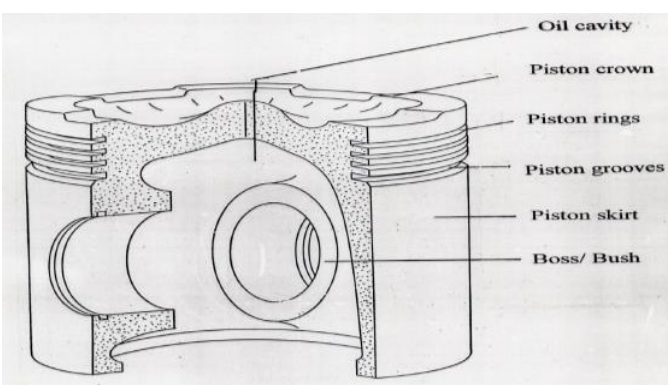

Figure 1: Main Features of Piston [12]

\section{METHODOLOGY}

In the design of pistons various parameters such as: piston bore diameter, piston stroke, indicated power, brake power, engine torque, mechanical efficiency, compression ratio, clearance volume, brake mean effective pressure and piston thickness were determined.

\subsection{Design Specification for Piston}

In specifying parameters for the piston design recourse was made to Table 1 . According to Heywood [13], other ranges of values are:

(i) Crank revolution for 2-stroke cycle is 1 , and for a 4-stroke cycle is 2

(ii) Maximum piston speed is between 8 to $15 \mathrm{~m} / \mathrm{s}$

(iii) Mechanical efficiency is $90 \%$ for speed range of 1800 to $2400 \mathrm{rpm}$ and $75 \%$ at maximum rated speed of 3000rpm

(iv) Brake mean effective pressure, $b_{\text {mep }}$ is between 850 to $1050 \mathrm{Kpa}$ at maximum engine speed of 3000rpm

\subsection{Design Assumptions}

(i) Volumetric displacement of $85 \mathrm{~cm}^{3}$

(ii) Compression ratio of $1: 10$

(iii) Mechanical efficiency of $75 \%$

(iv) Maximum speed of 3000rpm

(v) Engine cycle of 2-stroke cycle

\subsection{Design for Swept Volume of the Piston in the I.C. Engine}

Swept volume of an internal combustion engine implies the amount of charge being swept when piston reaches the Top Dead Centre (TDC) from the Bottom Dead Centre. It is determined by using equation (1) obtained from [14]

$$
V_{s}=\frac{\pi N D_{b}^{2} p_{s}}{4}
$$

where, $\mathrm{N}=$ number of cylinder; $\mathrm{D}_{b}=$ Piston bore diameter; $\mathrm{p}_{\mathrm{s}}=$ Piston stroke; $\mathrm{V}_{\mathrm{s}}=$ Swept volume In this study a swept volume of $85 \mathrm{~cm}^{3}$ (Tiger 950 generator) was used.

Table 1: Internal Combustion Engine operating data [13]

\begin{tabular}{|c|c|c|c|c|c|c|c|c|c|}
\hline \multirow[t]{2}{*}{ Engine Type } & \multirow{2}{*}{$\begin{array}{l}\text { Operating } \\
\text { Cycle }\end{array}$} & \multirow{2}{*}{$\begin{array}{l}\text { Compression } \\
\text { Ratio }\end{array}$} & \multirow{2}{*}{$\begin{array}{l}\text { Bore } \\
(\mathrm{m})\end{array}$} & \multicolumn{6}{|c|}{ Rated Maximum } \\
\hline & & & & $\begin{array}{l}\text { Strokel } \\
\text { bore }\end{array}$ & $\begin{array}{l}\text { Speed, } \\
\text { (rpm) }\end{array}$ & $\begin{array}{l}\text { Bmep, } \\
\text { (atm) }\end{array}$ & $\begin{array}{c}\text { Powerl } \\
\text { unit } \\
\text { volume, } \\
\mathrm{kW} / \mathrm{dm}^{3}\end{array}$ & $\begin{array}{c}\text { Weight/ } \\
\text { Power } \\
\text { ratio, } \\
\mathrm{kg} / \mathrm{kW}\end{array}$ & $\begin{array}{c}\text { Approx. } \\
\text { Best } \\
\text { bsfc, } \\
\text { g/kW.h }\end{array}$ \\
\hline \multicolumn{10}{|c|}{ Spark-ignition Engines: } \\
\hline $\begin{array}{l}\text { Small (e.g., } \\
\text { Motorcycles) }\end{array}$ & $2 \mathrm{~S}, 4 \mathrm{~S}$ & $6-11$ & $0.05-0.085$ & $1.2-0.9$ & $4500-7500$ & $4-10$ & $20-60$ & $5.5-2.5$ & 350 \\
\hline Passenger Car & $4 S$ & $8-10$ & $0.07-0.1$ & $1.1-0.9$ & $4500-6500$ & $7-10$ & $20-50$ & $4-2$ & 270 \\
\hline Trucks & $4 \mathrm{~S}$ & $7-9$ & $0.09-0.13$ & $1.2-0.7$ & $3600-5000$ & $6.5-7$ & $25-30$ & $6.5-2.5$ & 300 \\
\hline $\begin{array}{l}\text { Large Gas } \\
\text { Engines }\end{array}$ & $2 S, 4 S$ & $8-12$ & $0.22-0.45$ & $1.1-1.4$ & $300-900$ & $6.8-12$ & $3-7$ & $23-35$ & 200 \\
\hline Wankel Engines & $4 \mathrm{~S}$ & $\approx 9$ & $\begin{array}{l}0.57 \mathrm{dm}^{3} \\
\text { /chamber }\end{array}$ & & $6000-8000$ & $9.5-10.5$ & $35-45$ & $1.6-0.9$ & 300 \\
\hline
\end{tabular}


The various components of the piston and cylinder of an internal combustion engine are shown in Figure 2.

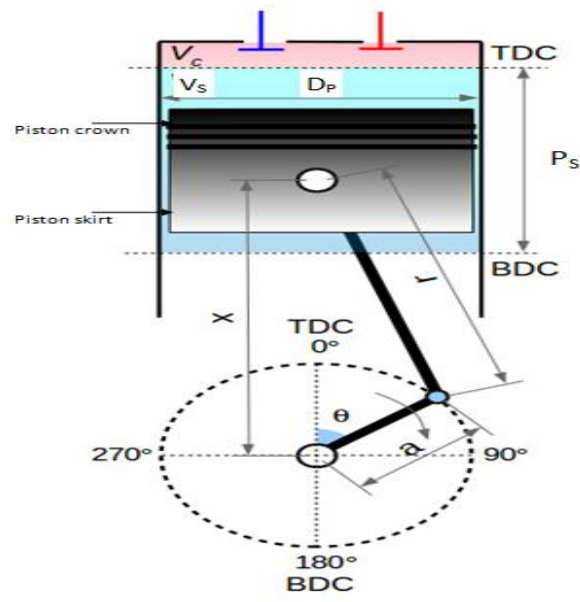

Figure 2: Piston and cylinder geometry [15]

\subsection{Design of Piston stroke and Bore diameter}

The bore diameter was determined from the swept volume using equation (2). For small and medium sized engines, the ratio of bore diameter to piston stroke which lies between 0.8 and 1.2 as shown in Table 1 is given as:

$$
R_{p s}=\frac{D_{b}}{p_{s}}
$$

Where $R_{p s}=$ ratio of bore diameter to piston stroke. It is assumed to be 0.9 for this study.

The bore diameter was determined by substituting for the ratio of bore diameter to piston stroke in equation (2). Substituting 0.9 into equation (2) gives

$$
D_{b}=0.9 p_{s}
$$

Solving equations (3) and (1) together yields equation (4)

$$
85=\frac{\pi \times 1 \times\left(0.9_{p s}\right)^{2} p_{s}}{4}
$$

Solving equation (3) and (4) together yields piston stroke of $51.00 \mathrm{~mm}$ and bore diameter of $45.85 \mathrm{~mm}$.

\subsection{Design for Torque}

The engine torque, $T$ was determined from the relationship between brake mean effective pressure and swept volume in $\mathrm{dm}^{3}$ obtained from [16]

$$
T=\frac{M_{e p \times V_{s}}}{6.28 n_{g}}
$$

where $M_{\mathrm{ep}}=$ mean effective pressure, $\mathrm{V} s=$ swept volume and $n_{g}=$ number of revolution per cycle The brake mean effective pressure of spark ignition engines is maximum at 3000rpm range of 850 -
1050Kpa as stated in Table 1. For this study it is taken to be $860 \mathrm{Kpa}$.

The engine torque was determined by substituting for the brake mean effective pressure and swept volume in $\mathrm{dm}^{3}$ in equation (5). The determined value of torque is shown in equation (6)

$$
T=\frac{0.86 \times 85}{6.28 n_{g}}=11.633 \mathrm{Nm}
$$

The maximum torque is determined to be $11.633 \mathrm{Nm}$.

\subsection{Design of Indicated Power}

The indicated power was determined by using equation (7).

$$
\text { Mechanical efficiency }=\frac{\text { Brake power }}{\text { Indicated power }}
$$

For small internal combustion engines having maximum speed of 3000rpm a mechanical efficiency of $75 \%$ is applied. The engine power, $\mathrm{P}$ in terms of torque is determined by equation ( 8 )

$$
P=2 \pi T N
$$

where $\mathrm{N}=$ speed in rev/sec, $\mathrm{T}=$ Torque

The brake power, $\mathrm{Pb}_{\mathrm{b}}$ was determined by substituting for maximum torque in equation (8), $P_{b}=2 \pi \times$ $11.633 \times 50=3655.0 \mathrm{Watt}$

The indicated power, $\mathrm{P}_{\mathrm{i}}$ is determined by substituting for brake power in equation (7) and taking mechanical efficiency to be $75 \% ; \quad P_{i}=\frac{3655}{0.75}=$ $4873.3 w$

The design for power is within the range of 1.5 to $5 \mathrm{Kw}$ for small spark ignition engines as stated in Table 1.

\subsection{Design for the Mean Effective Pressure of the Engine}

The mean effective pressure, $M_{e p}$ was determined by the ratio of network done to the swept volume of the piston as given in equation (9) also obtained from [16]

$$
M_{e p}=\frac{2 \pi T N}{V_{s}}
$$

The mean effective pressure, Mep was determined by substituting values into equation (9) as $M_{e p}=$ $\frac{2 \pi \times 11.633 \times 50}{85}=43.00 \mathrm{Mpa}$. The Mean Effective Pressure, Mep obtained is $43.00 \mathrm{Mpa}$

\subsection{Design for the Piston Thickness}

The piston thickness, $t_{p}$ was determined by using the equation (10) obtained from [17]. 


$$
t_{p}=\frac{P_{\max } \times D_{b}}{2 f_{c}}+K
$$

where, $P_{\max }=$ Maximum gas pressure on piston, $\mathrm{N} / \mathrm{mm}^{2}, \mathrm{k}=$ reboring factor and $\mathrm{f}_{\mathrm{c}}=$ maximum hoop stress $\mathrm{N} / \mathrm{mm}^{2}$

Maximum gas pressure on piston ranges between 3.1 to $3.5 \mathrm{~N} / \mathrm{mm}^{2}$ [17]. For this study it is taken to be $3.4 \mathrm{~N} / \mathrm{mm}^{2}$, for a bore diameter of $45.85 \mathrm{~mm}$ the selected reboring factor is 1.5 as specified by [18]. Maximum hoop stress of $45 \mathrm{~N} / \mathrm{mm}^{2}$ was selected from a range of between 35 to $105 \mathrm{~N} / \mathrm{mm}^{2}$. The piston thickness, $t_{p}$ was obtained by substituting for maximum gas pressure and maximum hoop stress in equation (10): $t_{p}=\frac{3.4 \times 45.85}{2 \times 45}+1.5=3.232 \mathrm{~mm}$. The piston thickness obtained is $3.232 \mathrm{~mm}$. The relationship between empirical piston thickness and the bore diameter is given in equation (11)

$$
t_{p} \geq \frac{D_{p}}{15}
$$

The empirical piston thickness is determined by substituting for the bore diameter in equation (11)

$$
t_{p} \geq \frac{45.85}{15}
$$

The result shows that the empirical piston thickness is 3.056. The designed thickness falls within the acceptable range because it is greater than empirical value of 3.056

\subsection{Design for Clearance Volume of the Combustion chambers}

The clearance volume was determined using the equation (12) obtained from [18]

$$
r_{c}=\frac{V_{s}+V_{c}}{V_{c}}
$$

where, $r_{c}=$ compression ratio between 8 to 12 for spark ignition engines, $V_{s}=$ swept volume and $\mathrm{V}_{\mathrm{c}}=$ clearance volume.

For this study the compression ratio selected is 10 The clearance volume was determined by substituting for the selected compression ratio, $r_{c}$ and the swept volume, $\mathrm{V}_{\mathrm{s}}$ in equation (12)

$$
10=\frac{85+V_{c}}{V_{c}}
$$

The Clearance volume determined, $V_{c}$ is $9.44 \mathrm{~cm}^{3}$

\section{RESULT AND DISCUSSION}

\subsection{Modeling of the piston}

The diagrammatic modeling was done using AutoCAD 2016 . An isometric drawing and the first angle projection of the designed generator piston is shown in Figures 3 and 4 respectively

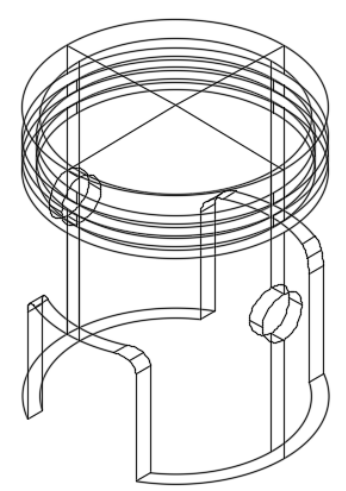

Figure 3 : Isometric drawing of piston
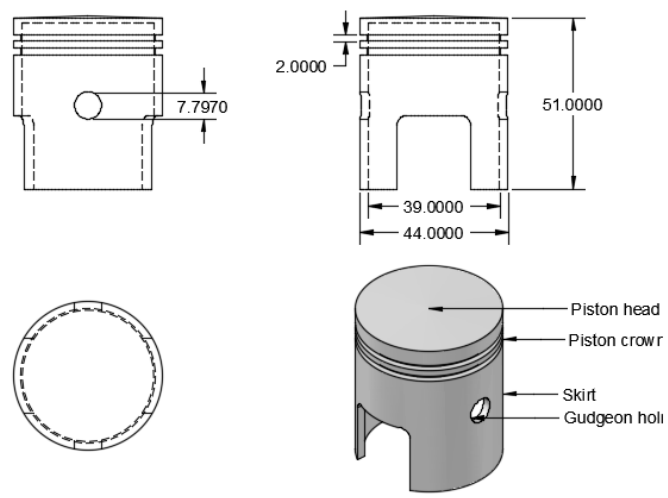

Figure 4: First Angle Orthographic Projection of the Piston

\subsection{Summary of the piston design parameters}

The designed parameters and their recommended values for small engines are shown in Table 2.

Table 2: Piston designed data and recommended values for small engines

\begin{tabular}{lll}
\hline Parameters & $\begin{array}{l}\text { Designed } \\
\text { value }\end{array}$ & $\begin{array}{l}\text { Recommended } \\
\text { values }\end{array}$ \\
\hline Swept volume & $85 \mathrm{~cm}^{3}$ & - \\
Clearance volume & $9.44 \mathrm{~cm}^{3}$ & - \\
Indicated power & $4.873 \mathrm{Kw}$ & $1.5-5.0 \mathrm{Kw}$ \\
Brake power & $3.655 \mathrm{Kw}$ & $1.5-5.0 \mathrm{Kw}$ \\
Bore diameter & $45.85 \mathrm{~mm}$ & $50 \mathrm{~mm}$ \\
Piston stroke & $51.00 \mathrm{~mm}$ & $45-76.5 \mathrm{~mm}$ \\
Piston thickness & $3.22 \mathrm{~mm}$ & $>3.01$ \\
Engine torque & $11.633 \mathrm{Nm}$ & - \\
Engine Mean effective & $43.00 \mathrm{Mpa}$ & - \\
pressure & & \\
\hline
\end{tabular}

\section{CONCLUSION}

It important for Nigerian automotive engineers to complement the effort of Nnewi based auto spare parts production companies so as to discourage the massive importation of pistons from United States of America (Wiseco Piston Company), Japan (Izurmi Industries Ltd) and India (Anand Piston Inc.). Building indigenous capacity for the production of 
generator pistons in Nigerian technological sphere may stimulate a very great boost.

Past study on piston development done by some Nigerian researchers employed reverse engineering in the development of internal combustion engine components rather than detailed design.

This study was carried out to fill the gap created by the constant application of Reverse engineering in the manufacture of generator pistons. A $0.67 \mathrm{hp}$ piston used in Tiger 950 generator was successfully designed. The designed values of the piston parameters were in accordance with the recommended range for small internal combustion engines.

\section{REFERENCES}

[1] Srivathsan, S. "Comparative Study of Aluminium Alloy Pistons Manufactured by Casting and Powder Forging", International Journal of Scientific and Engineering Research, Vol. 5, Number 6, 2014, pp.662-665.

[2] Rohrle, M. D. Pistons for Industrial Combustion Engines, Verleg Modern Publishers, Stuggart, Germany, 1995.

[3] Degobert, P. Automobiles and Pollution, Third Edition, Technips Publishers, New York, U. S. A., 1995.

[4] Ghomashchi, R. Semi-solid Processing of Aluminium, Springer International Publishing, New York, U. S. A, 2016.

[5] Ekesiobi, C.S. Kalu U. D. and Nwokolo, C "Industrial Clusters and Industrialisation in Nigeria: A Micro-Assessment of the Nnewi Automotive Component Industrial Cluster, Anambra State", The Nigerian Journal for Economic and Social Studies,Vol. 60, Number 3, 2018 pp. 133-155

[6] Brautigam, D. "Substituting for the state: Institutions and industrial development in Eastern Nigeria" World Development, Vol. 25, Number 7, 1997, pp. $1063-1080$.

[7] Ohwojero, C. and Ede, E. C. "History of Automobile Past and Present Challenges Facing Automobile Production in Nigeria" Journal of Research \& Method in Education, Vol. 2, Number 4, 2013, pp. 11-16.

[8] Ebhota, W.S. ,Ademola, E., Abdulrahman, J., Aduloju, S. C., and Owolabi, O. B. "Designing for domestication of Yamaha CY80 Engine Piston
Manufacturing Technology and Evaluation of Aluminium Alloy for Functionality", International Journal of Advanced Scientific and Technical Research, Vol. 1, Number 5, 2015, pp. 21-34

[9] Ebhojaiye, R. S. and Ibhadode, A. O. A. "Production of a Piston for a Single-cylinder,four stroke, $8 \mathrm{Hp}$ Diesel Engine by Reverse Engineering Technique", The Journal of the Nigerian Institution of Production Engineers, Vol. 15,Number 3, 2013, pp 80-88.

[10] Amalu, E. N. and Ibhadode, A.O.A. "3Hp Petrol Engine Block Fabrication by Reverse Engineering Approach", Nigerian Journal of Research and Development, Vol. 6, Number 2, 2007, pp 1-6

[11] Mahdy, H. F., Enab, T.A., Galal, A. M., and Samuel, M. "Experimental Study of Manufacturing Aluminium Alloy Pistons using Vertical Centrifugal Casting Process", International Journal of Scientific and Engineering research, Vol. 7, Number 8, 2016, pp. 198-204.

[12] Ogbonnaya, E.A., Nwankwojike, B. N., Adigio, E. M., Fadeyi, J. A. and Nwogu, C. N., Development of CNC Program for Piston Production, "Journal for Materials Processing", Vol. 1, Number 4, 2014, pp.117-122

[13] Heywood, J. B. Internal Combustion Engine Fundamentals, McGraw-Hill, New York, U. S.A., 1988

[14] Khurmi, R. S. and Gupta, J. K. Theory of Machines, Fourteenth Edition, Eurasia Publishing Ltd, New Delhi, 2008.

[15] Sathishkumar. S. Design and Analysis of IC engine Piston using Catia and ANSYS Software, M.Eng Thesis, Department of Mechanical Engineering, S. K. F. College of Engineering, India, 2015.

[16] Kaisan M. U. and Pam G. Y. "Determination of Engine Performance Parameters of a Stationary Single Cylinder Compression Ignition Engine", Journal of Energy, Environment \& Carbon Credits, Vol.3, Number 3, 2013, pp. 15-21

[17] Sharma, P. C. and Aggarwal, D. K. A Textbook of Machine design. Twelveth Edition, S. K. Kataria and Sons, Daryaganj, New Delhi, India, 2013.

[18] Ebhojiaye, R.S. and Sadjere, G.E "Design of cylinder Block of an 80cc Spark Ignition (SI) Aluminium Engine",Pacific Journal of Science and Technology, Vol. 18, Number 1, 2017 pp. 22- 30. 